\title{
TASK-BASED LANGUAGE LEARNING AND TEACHING (ACTIONABLE PERSPECTIVE) OF FRENCH IN SECONDARY SCHOOLS IN KENYA
}

\author{
Leonorah Ceciliah Mugalla Lutiali ${ }^{1} \bowtie$, Dr. Adhelheid Marie Bwire ${ }^{2}$, Samson Ondigi Rosana ${ }^{3}$ \\ ${ }^{1}$ Ph. D student, Department of Communication Skills and Educational Technology Kenyatta University, Kenya. \\ ${ }^{2}$ Chairman, Department of Communication Skills and Educational Technology Kenyatta University, Kenya. \\ ${ }^{3}$ Professor, Department of Communication Skills and Educational Technology Kenyatta University, Kenya.
}

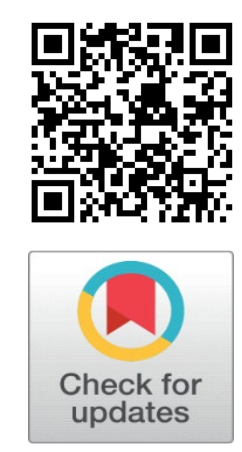

Received 4 September 2021

Accepted 17 September 2021

Published 30 September2021

\section{CorrespondingAuthor}

Leonorah Lutiali,

addiemarie2010@gmail.com

DOI

10.29121/granthaalayah.v9.i9.2021. 4128

Funding: This research received no specific grant from any funding agency in the public, commercial, or not-for-profit sectors.

Copyright: (C) 2021 The Author(s). This is an open access article distributed under the terms of the Creative Commons Attribution License, which permits unrestricted use, distribution, and reproduction in any medium, provided the original author and source are credited.

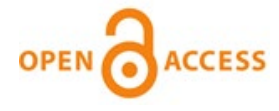

\section{ABSTRACT}

The nature and extent to which tasks are used in quality writing using the Task-Based Learning and Teaching (TBLT) is important in acquisition of French language. According to the Kenya National Examination Council (KNEC) reports, performance in quality writing in French is poor maybe because teachers of French may be using TBLT only in teaching. The purpose of this study was to assess the Task-Based Language Learning and Teaching (Actionable Perspective) of French in secondary schools in Kenya. The objective was to establish the nature and extent of TBLT use. The study was carried out in Nairobi City County where eight (8) secondary school teachers of French in Form three and one hundred and twenty-four (124) Form three students formed the study sample. A quasiexperimental research design was used. The data collection instruments were; teachers' and learners' questionnaires and a lesson observation guide. These instruments for data collection were refined through a pilot study. Data was analyzed qualitatively and quantitatively using descriptive statistics (means, ranks, frequencies, percentages, standard deviation). It was presented in frequency tables and bar charts. The findings were that TBLT was not only being used in teaching and learning but also in assessment and choice of learning resources. The study recommended use of TBLT alongside other methods, review of text books in line with TBLT, inclusion of TBLT in the syllabus at the teacher-training colleges/universities and mentorship programs in TBLT.

Keywords: Learning, Teaching, French, Schools, Language

\section{INTRODUCTION}

The task-based approach has been embraced globally, regionally and nationally in the teaching and learning of French. In the United States of America, Task-Based Approach led to the emergence of Web 2.0 concepts where a potential educational environment was created in which students got access to a widely distributed, authentic audience with a simple click on the mouse (Julian \& Kimberly, 2016). An investigation into teacher perceptions towards TBLT in the Canadian context showed that teachers used TBLT in all their lessons and that teachers used essays, interviews and presentations as forms of writing in TBLT.

The Malysian Communication Syllabus (1978) and the Bangalore Project (1987) were some of the studies done in TBLT. The research by Leaver \& Kaplan (2004) assessed the benefits of TBLT which included: curriculum flexibility, natural correction of error, high proficiency, greater motivation, promoted how to learn, repetition without boredom, promoted risk taking and increased student satisfaction. 
In Reunion Island, Olivier (2018) differentiates between two types of tasks, thus tasks that reflect real-life use and pedagogical tasks. The study established the role of the teacher in TBLT. These were; the teacher energized and motivated learners in the task, provided adequate and appropriate instructions for task and provided support and interacted with learners when needed.

A Research on 'Cognitive Task Analysis in Task-Based Syllabus Design for the teaching of Kiswahili as a Second Language' in Uganda Ceasar (2018) showed that in order to design a task-based Kiswahili syllabus, task themes, task description, simulated task dialogues were used as a primary input. Findings indicated that while designing task-based syllabuses, all the task features such as cognitive, interactional and syntactic properties were taken into account.

According to Willis (2011), the Task-Based language teaching has five types of tasks, which are; Jigsaw, information gap, problem solving, decision making and opinion exchange tasks. All these tasks are important in improving the learners' quality writing which is important in that it opens up more possibilities for learners compared to the other language skills of reading, listening and speaking (Panavelil ,2015). Despite training and competence in teaching using various approaches, teachers still face the challenge of teaching quality writing in French. The major problems in the writing skill according to both teachers and students include; finding a suitable vocabulary, use of appropriate tenses, correct spelling, punctuations, organizing ideas neatly and coherently in paragraphs.

According to Parson (1985), examples of tasks that enhance quality writing include; regular reading, journaling, story prompts, creating blogs, e-mail writing, crossword puzzles, word games, picture stories and free writing. The teacher has the role to create a language rich environment through grammar instruction, sentence combination, audio-visual stimulation and encouraging poetry writing.

\section{Nature and extent of Task-Based Language Teaching use.}

The two types of writing are communicative and academic writing. Task Based Approach was introduced as an approach of teaching French in the Common Reference for Languages (CECRL,2001). A task has four main characteristics; (a) it involves a primary (pragmatic) focus on meaning, (b) it has some kind of gap, (c) participants choose the linguistic resources needed to complete the task and (d) it has a clearly defined, non-linguistic outcome. It emphasizes purposeful and functional language use by using real-life tasks in the classroom for students to experience learning. Although this method is not a departure from other methods, it presents a model that is based on sound theoretical foundations and it takes into account the need for authentic communication.

Nunan (2004) defines the communicative task as a piece of classroom task which involves learners in comprehending, manipulating or interacting in the target language while their attention is focused on meaning rather than form. Examples of tasks involve visiting a doctor, carrying out an interview, booking a ticket or calling customer service for help. While the study reviewed focused on the type of tasks, the current research focused on the extent to which these tasks are used in teaching writing. In the present study, a task is defined in terms of writing a dialogue between a seller and buyer of tickets at the railway station.

Ellis (2003), categorizes tasks into focused and unfocused tasks depending on the way they are performed and not on their design. Listening tasks are valid for comprehension and interpreting new materials. Writing tasks which is the focus of this study are valid for communication, stimulating interest or reflecting on personal experiences and learning from them. Although Ellis (2003) gives us the 
categories of tasks, the linguistic competence of a task is not considered. Contrary to the above research, the current study used the linguistic competence on the marking scheme as one of the evaluation indicators that tested quality composition writing.

Prabhu (1987) identified three main types of tasks as; Information gap which involves a transfer of given information from one person to another. Reasoning gap involves deriving some new information from given information through processes of inference, deduction or reasoning. Opinion gap activity involves identifying and articulating a personal preference, feeling or attitude in response to a given situation. In this study where the nature and extent of TBA was assessed, the researcher observed the tasks in the classroom thus; role playing, dramatizing, filling in gaps, listening and watching video clips. These tasks fall under the above three main types as identified by Prabhu. Although Prabhu (1987) identified the main tasks, the extent to which they were used was not studied. In the current study, the extent to which tasks were used in writing was investigated.

Youssef, (2010) outlines the characteristics of the TBLt class as follows; When the students' attention is focused on the task, it is much easier to learn the grammar items well. The purpose of language learning is not just learning grammar knowledge, but practical use of grammar knowledge. Contrary to the study by Youssef (2010), the present research evaluated grammar in writing a quality dialogue between a seller and a buyer of tickets under linguistic competence.

In order to make the tasks in TBLT more meaningful and interesting, according to Youssef, (2010) the grammar class asks for student co-operation. A teacher is no longer a dominator in class but a facilitator of learning. The student individuality is appreciated and learners learn from one another. More fun and interest in learning together where learners are allowed to use whatever language they want is experienced in TBLT. This makes it closer to a real-life communicative situation. While the studies reviewed above focused on the role of the teacher and learner to make TBLT meaningful, the current study focused on how often teachers use TBLT, instructional resources, co-curricular activities that enhance tasks in order to make TBLT interesting and meaningful.

According to Skehan (1994), TBLT has two important goals thus; (i) Accuracy which is defined as how well language is produced in relationship to the rule system of the target language and (ii) Fluency - which concerns the learners' capacity to produce language in real time without undue posing or hesitation. While the above study focused on the rule system of the target language to test accuracy and fluency, in the present study, accuracy and fluency were evaluated through the 4 evaluation indicators of adherence to instructions, communicative, textual and linguistic competences and various other assessment methods used in TBLT.

Seetha (2004) in research on 'A critical review of the Tamil Language and Syllabus in TBLT' notes that grammar teaching is not central because learners will acquire the required grammar as a by-product of carrying out tasks and activities. The researcher suggested the introduction of a drama syllabus and texts with approaches to oral language. While the studies above looked at Tamil language and TBLT syllabus, in the present research on TBLT in quality writing of French composition, the focus was on French language and the resources used to make TBLT effective in writing.

\section{Teaching writing skills using the Task-based lesson plan}

Willis (2011) sample of the Task Based Lesson Plan proposes three cycles; pretask, task and language focus. At the pre-task level, the teacher introduces the topic 
and the task. Techniques such as brainstorming, matching phrases to pictures and choosing the odd one out can be used. At this stage, the teacher may divide the learners into pairs or small groups. The learners engage in activities that will either help them to recall words and phrases that will be useful during the performance of the main task or to learn new words and phrases that are essential to the task.

At the task cycle, the teacher walks around the groups to listen to what the students are discussing without correcting them. At this level, the learner performs the task using the language they already know and the learner is given an opportunity to improve on that language. The tasks may include either a reading, listening, writing or speaking or a problem-solving exercise. By this stage, the learner has experienced motivation and use of the language. The students will then prepare a report for the whole class on how they did the task and what conclusions they reached. Reports are important because that is when students start worrying more about accuracy rather than fluency. In addition, reports are useful for creativity, listing, comparing and problem solving.

At the language focus emphasis is laid on learning language form. The teacher examines and discusses specific structures that are used during the task and corrects students' mistakes. Specific language features from the task are highlighted and worked on. The teacher gives feedback on the learners' performance and corrects them at this level. Practice on these features, such as drillings, listening and completing, memory challenge, dictionary exercises and computer games are given at this stage. Although Willis (2011) presents an ideal TBLT lesson plan, in the current study modifications were made on it to include the methods and resources used, non-verbal communication and assessment of tasks.

In this study on TBLT in quality writing, the learner was required to write a dialogue using the conditional 'conditonnel', as a polite form of conversing with a seller of tickets who is a complete stranger. Therefore, the learner was to be taught how to use this tense before writing the dialogue. Clanfield (2014) illustrates the practical use of Willis (2011) flexible task-based learning lesson plan to teach the grammar conditional tense 'would have' 'in French, 'Le conditionnel'.

At the pre-task level, the learners watch a video clip of four people from different cultures Thailand, Seychelles, Serbia and France. After this, students were expected to say what they thought the people were saying and the teacher accepted all the answers making no corrections at this level. At the task level, students were to work in groups of three and discuss how they would say in their own culture. The learners were to compare the expressions from the different cultures to the French expressions. They would then put the given French expressions of politeness in order and make a list of other expressions that express the polite form. These expressions would include Bonjour - Hello, Excusez-moi - Excuse me, combien coûte un billet s'il vous plait? - How much is a ticket please? Merci - thank you, Au revoir Bye bye.

At the planning stage, the students would prepare an oral report about the mini-tasks and activities they had done and present it at the report stage in an oral form. At the language focus, the teacher would raise awareness about the target language which was French by choosing two or three sentences and writing them on the board. The teacher would then explain the rule, that is; conditional of the auxiliary verbs 'avoir' or 'etre' + the infinitive. The conditional would have the imperfect endings (-ais, -ais, - ait, ions, - eiz, - aient). For most verbs, the stem consists of the infinitive less any final ' $e$ '.

At the language practice stage, the teacher would ask the students to write down two things they would have liked to do. In this case they would write: Je voudrais acheter un billet (I would like to buy a ticket). J'aimerais voyager demain 
matin (I wou ld love to travel tomorrow morning). For optional follow up the students would be given a chance to repeat the process so that they could improve on the task. The teacher could ask a couple of students to report back to the class. This is the time to focus on accuracy i.e., the teacher corrects what the students say. In this research, grammar was evaluated under the linguistic competence as an evaluation indicator. Table 1 shows a model lesson plan for a task-based approach adapted by Willis (2011).

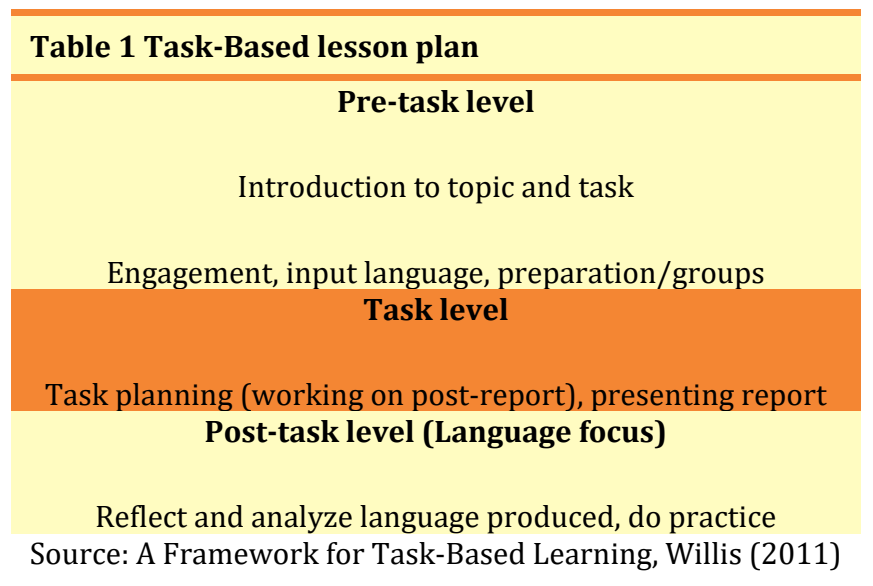

In a feasibility study of Task-Based Language teaching in college English composition writing in a Chinese EFL context in China, Jane Willis Framework of Task-based teaching was used to examine the effects on the improvement of English composition writing on learners (Linying, 2012). The qualitative and quantitative data yielded from a quasi-experimental design revealed that the application of the framework had a positive influence upon college EFL learners. The learners understanding of a good piece of English writing helped them solve problems related to composing which consequently improved their competence in composition writing. Contrary to Linying, 2012, which was based on English composition writing, the current study was based on French composition writing among secondary school students.

\section{Instructional Resources in TBA}

Hughes (2014) states that instructional materials development in any teaching/learning environment is based on the students' needs analysis, learners' proficiency levels and the course curriculum. According to Hughes (2014), there are two types of curriculums; the Topic-based and the Task-based curriculum. A topicbased curriculum focuses on what the learner needs to know and produces learners who know about tasks they need to perform after training. On the other hand, a Task-based curriculum produces learners who can perform the tasks needed to succeed at their job, provides learners with content and shortens the time to proficiency. Contrary to the above study, in this study, the sampled teachers responded to a questionnaire in which they highlighted the type, availability and use of learning resources and how well they responded to teaching composition writing using TBLT.

According to Ortiz (2006), the TBLT curriculum has a particular scenario which will make sense to the tasks and has both communicative and linguistic objectives which are selected specifically to respond to the needs of the learner. In addition, a curriculum on TBLT, involves putting in mind the knowledge of how to perform on the international market. The global coherence of the curriculum rests on the 
actionable perspective and considers the learner as the social actor to execute tasks in the immediate environment. Although the above study looked at the advantages of a TBLT curriculum, in the present study on the effectiveness of TBLT on quality writing, a real-life scenario was created through the test question where the learner was at a railway station in a francophone country and desired to purchase a ticket to travel to his own country. Ortiz (2006) notes that a TBLT curriculum has to be multidimensional. That is, it has to be presented in the form of a table and has to have the following categories; linguistic skills, communicative objectives which are both cultural and intercultural, activities and modalities of executing them, support materials and topics. In the present research, the researcher did not look at the dimensions of a TBLT curriculum but used the lesson observation form which to observe these dimensions in class.

A study on 'Availability and use of teaching and learning resources in Public Diploma Teachers' Training colleges by Wanjiru (2009) recommended that the administration 'in-services' teachers and ensures that they always make the best use of the teaching and learning resources during their lessons. A similar concept was introduced by the Embassy of France in the training of teachers of French in secondary schools in Kenya on the use of the resource materials. Although Wanjiru (2009) looked at availability and use of resources in Diploma teacher colleges, the current study focused on availability, use and type of resources in secondary schools in Nairobi City County.

The tasks on the internet cannot be ignored in a world inhabited by technology and the social reports transformed by its use. Penilla (2009) posits that on the internet, learners may find an author who has created his own blog, a character in a play on the net or a client of a commercial platform. The role given to the actors of these scenarios gives them the possibility to become authors considering what they have observed on the internet. On entry on Facebook for example, the learner performs is given the chance to perform a social act accepted just like a writing stimulated task. Contrary to Penilla (2009), in the Task-Based Approach and composition writing, which was the focus of this study, learners may be asked to create their own blogs, make comments on already existing blogs or to send an email which would help them improve their composition writing skills.

In January 2012, the Ministry of Education and Vocational Training, the Prime Minister's office and the Embassy of France under the coordination of the Tanzania Institute of Education (TIE) held a five-day special seminar in a secondary school in Tanga Region for French language teachers on how best to employ the internet in language training and learning. The main objective was how to use TV 5 Monde, a French program TV channel from which French programs are derived. This was presided over by Frederique Gellam, an expert in French Language teaching from CAVILLAM, Centre d'Approaches Vivantes de Langues et Media (Center of Modern Approaches for Languages and Media) in Vichy, France. In the present study, the teachers of French in secondary school were taught how to get teaching resources on TV 5 Monde during the TBA training.

\section{Assessment in TBA}

Assessment plays a very essential role in the learning and teaching process. According to the Common European Framework for References for languages (CECR), (2001), there are three concepts to be considered in assessment, thus validity, reliability and practicability. According to Brindley (2012), the Task-Based Approach uses four types of assessments: Formative, Performance referenced, Direct and Authentic assessments. Goullier (2006) posits that auto-evaluation, which is part of formative assessment is a motivating factor which helps learners to 
identify their strong and weak areas. It encourages autonomous learning which reinforces mastery and consciousness in learning. In addition, it assists in organized and planned learning where the learners focus on their capacity to communicate in languages, they have not learnt formally but which contribute to their multilingual developments. In this research on effectiveness of TBLT in quality composition writing, where the learner was required to write a dialogue between a buyer of a ticket and the seller, only formative evaluation was used. In this study, the lesson observation was used to find out whether teachers used auto evaluation or teacher evaluation.

\section{Evaluation indicators in TBLT}

Lavabre (2002) on Adherence to instructions as an evaluation indicator argues that instructions should be written in such a way that learners will be autonomous outside the lesson in their practical work. An instruction has to be clear, brief and precise without using complicated words. In his study, he found out that $60 \%$ of the students did not have a problem with following instructions during a composition writing test.

\section{METHODOLOGY}

\section{Research Design}

The study employed a quasi-experimental design and 8 schools were used. This design was appropriate for the present study because it was conducted in a classroom setting and so assigning subjects randomly was not possible. The independent variables were manipulated without random assignment of participants. Both qualitative and quantitative data was obtained and analyzed. Creswel (2009) posits that more insight is gained when both qualitative and quantitative data is analyzed in order to address complex problems.

\section{Variables of the Study}

The independent variables in this study were: Nature and extent of Task-Based Approach use, teachers' and learners' perceptions towards Task-Based Approach, type, availability and use of instructional resources. Secondly, the intervening variables were; learner's entry behavior, learning environment and institutional policies. The extraneous variable was the challenges of using TBLT in quality writing.

\section{Locale of the Study}

The study was carried out in Nairobi City County which is the capital city of Kenya. This County boarders Kiambu, Machakos and Kajiado counties. Nairobi City County was chosen because being the capital city of the country, it is assumed to have well trained teachers and adequate instructional resources to teach quality writing. However, according to the KNEC reports of the last five years, its performance in composition writing is slightly low compared to the neighboring counties of Kiambu and Machakos. Moreover, Nairobi City County being a capital city in Kenya has all types of schools and institutions that learn foreign languages, French inclusive and getting data related to French was easier as compared to other counties.

Purposive sampling was used to choose the eight schools to include all the categories of schools, that was; Public, Private, Girls, Boys and Mixed school. For 
schools that had more than one teacher of French, the form three teacher was used for the study. Form three was chosen purposively because at this level, they have selected French as one of their examinable subjects and it is assumed that they have mastered sufficient vocabulary to write a composition.

\section{Questionnaire to Teachers}

The questionnaire to the teachers (Appendix A) was administered by the researcher to the teachers of French after lesson observation. The questionnaire contained two sections. The first section contained descriptive information on the teacher and was filled in by the eight teachers in the study. The second section contained open-ended and close-ended questions which helped to answer the research questions.

In the objective on the nature and extent of TBA use, teachers were to provide information on how often they use TBA by ticking on suitable option from the five options; Always, Most of the time, A few times, not sure and never. In addition, they were to tick on the type of compositions they taught using TBA types of compositions; letter writing, dialogues, recipes, short stories, Curriculum vitae, essays, reports and posters as provided on the questionnaire. On the type of resources, they were expected to choose from the ten resources; Text books, photographs, drawings, photocopies authentic texts, radio, television, DVDs, CDs, computer and internet. As concerns the availability of resources, they were supposed to tick whether the resources were available all the time, sometimes or not available at all. Finally, on the use of instructional materials, teachers were expected to say whether they used them during all their lessons, some lessons, very few lessons or do not use resources at all when teaching composition writing. They were supposed to indicate the websites that they used to teach writing and the methods they used for evaluation.

\section{FINDINGS OF THE STUDY}

\section{To establish the extent and nature of TBLT use}

The study sought to find out the nature and extent to which TBLT was being used by asking the teachers to tick on how often they used TBLT in their lessons. The options were: Always, sometimes and never. This was also done using the lesson observation schedule during classroom observation where lesson objectives and lesson planning, content delivery, learner involvement in tasks and communication, forms of writing, resource materials/internet sites, types of tasks, classroom management and evaluation were determined in order to test the effectiveness of TBLT.

At the beginning, teachers were asked to state how often they used TBLT in teaching and whether they used Willis (2011) structure of a lesson plan in their lesson preparation. In addition, the teachers were supposed to tick on the appropriate resource materials and internet sites for teaching quality writing using TBLT and the type of evaluation they used assessing quality writing. Apart from the questionnaire, the lesson observation form was also used to gather the data on extent and nature of TBLT use.

The findings showed that the teachers set objectives according to the TaskBased Approach, that is: communicative, linguistic and (inter) cultural objectives. All the learners $(100 \%)$ were able to attain the communicative objective by the end of the lesson. This was done through writing out speech acts tasks like 'Bonjour' 'je voudrais...' while in the linguistic objective, the learners conjugated verbs in the present tense while writing and in the inter(cultural) objective, learners compared 
means of transport in Kenya and in France and used polite form; 's'il vous plait, merci, au revoir'. This is in line with CECRL (2001) which states that objectives need to measure all the three elements of communication, language and culture in teaching and learning.

All the teachers (8) reviewed their previous lessons before introducing the new task/topic. This was a requirement according to the TSC lesson observation form. Teachers in both public and private schools had been using these forms every time they were observed in class and so they did not have a problem in reviewing and linking the previous lesson to the new topic. From the findings, the topics were in line with the form 3 KICD syllabus, that is 'Les moyens de transport' 'Les voyages', 'Demander et dire le prix', 'Le conditionnel', 'Dire où l'on va'.

The findings showed that 3 teachers from the control group finished the lesson in the stipulated time of 40 minutes. This may be attributed to the fact that these teachers were time conscious in preparation and content delivery. 1 teacher in the control group exceeded the lesson by 5 minutes which may be attributed to giving special attention to the less active learners to ensure that they participated in the classroom activities. In the experimental group, all the 4 teachers $(100 \%)$ finished their lessons in the stipulated time of 40 minutes. This might have been because of the training they had received in TBLT where they had been taught how to effectively teach a lesson in 40 minutes using TBLT. Teachers are advised not to prepare to much content and also to do a rehearsal of the lesson inorder not to exceed the time given by the Ministry of Education.

The study found out that $100 \%$ of the teachers in the experimental group used the Willis (2011) structure of a task-based lesson plan to prepare their lessons. That was; Introduction (pre- task level), Lesson development (task level), Lesson conclusion (language focus and feedback). In the control group, only one teacher used the lesson structure by Willis. This might be because the teachers in the experimental group had been taught how to use this lesson structure during the TBLT training while the 1 teacher $(25 \%)$ in the control group might have used the previous knowledge gained during in-service training in TBLT. Teachers were therefore advised to use the TBLT lesson structure to teach writing of composition in French. According to Linying (2011), the application of the task-based framework had positive influence upon college ESL learners. Their understanding of a good piece of English writing helped them solve problems related to compositing which helped to improve composition writing.

\section{Forms of writing}

Learners were asked to tick on the forms of writing they learnt in class to find out the extent to which TBLT was being used. The forms of writing were; letters, dialogues, recipes, short stories, curriculum vitae, essays, reports and posters. The results were as shown in Table 2.

\begin{tabular}{|ccccccc}
\hline Table 2 Forms of writing & & & \\
Forms of writing & \multicolumn{7}{c}{ EXPERIMENTAL } & \multicolumn{3}{c}{ CONTROL } \\
\hline & N & Freq & Percent & N & Freq & Percent \\
\hline Letters & 60 & 58 & 97 & 64 & 62 & 97 \\
\hline Dialogues & 60 & 55 & 92 & 64 & 59 & 92 \\
\hline Recipes & 60 & 54 & 90 & 64 & 54 & 94 \\
\hline Short stories & 60 & 24 & 40 & 64 & 16 & 25 \\
\hline Curriculum Vitae & 60 & 53 & 93 & 64 & 62 & 97 \\
\hline
\end{tabular}




\begin{tabular}{cccccccccc}
\hline & Essays & 60 & 45 & 75 & 64 & 38 & 59 & 9.3 \\
& Reports & 60 & 2 & 3 & 64 & 6 & 9.3 \\
& Posters & 60 & 48 & 80 & 64 & 40 & 62.5
\end{tabular}

From Table 2, the study found out that $97 \%$ (58 out of 60 ) of the learners in the experimental group and 97\% (62 out of 64) in the control group used TBLT to write letters. This might be because letter writing is a type of functional writing that is mainly tested in KCSE French paper 1 (501/1). Letter writing tasks might have motivated the learners bearing in mind that they would be expected to write letters even after school to ask for employment or to correspond with others. As for dialogues, 92\% of the learners responded to using TBLT in learning in both the experimental and control groups. This might have been because the learners had been asked to write a dialogue in the pre-test and also in the post-test and so this knowledge helped majority of the students in answering the test on writing a dialogue between him and the seller of tickets at the railway station. Only $25 \%$ of the learners used Essay writing as a form of writing using TBLT. This lower number might be attributed to the fact that in secondary school, the national examination council (KNEC) does not test essay writing skills. However, according to the Ministry of Education policies, secondary school students are expected to take part in essay writing competitions (E-Kitabu \& East African Community Essay writing).

As for the writing of recipes, $90 \%$ in the experimental and $94 \%$ of students in the control group reported that they enjoyed using TBLT in writing recipes. This corroborates well with the teachers' feedback on recipe writing which also reported a higher percentage of use. Students reported that writing of recipes rendered them more active and especially when it came to the practical part of cooking using the recipe they had written. Both teachers and learners are encouraged to use TBA when teaching and learning how to write recipes as this gives the learner a chance to apply the practical knowledge during cooking and this will make learners remember the concepts with ease.

However, the findings revealed that very few students $3 \%$ ( 2 out of 60 ), in the experimental and 9\% (6 out of 64) in the control group enjoyed learning writing skills through writing reports. They reported that they lacked the relevant vocabulary to write reports on how they had performed various tasks. This might be because report writing requires that the learner acquires a more profound level of vocabulary that may not have been taught as they performed the tasks. However, according to Willis (2011) TBLT lesson structure, report writing is an important stage where focus is on accuracy and fluency of the language as the teacher corrects the learners' written work.

Findings from the lesson observation form showed that all learners were involved in tasks and they communicated in class. The tasks and activities observed were information tasks, classroom presentations, dramatization, role playing, jig saw tasks, scaffolding, brainstorming and storytelling. These tasks although oral helped to prepare students for the main task of writing a composition.

As concerns classroom management, findings from the lesson observation form showed all the eight teachers did not allow students to speak in mother tongue, make noise or give chorus answers. In order to implement this, it was observed that all the teachers knew the students in their classes by name, move around the class to check on students' work, allowed all students to participate by asking and answering questions. It was also observed that all the teachers catered for the individual needs of students by giving each a task to carry out in the groups. This is 
an important element in TBLT teaching quality writing so that all students are motivated to learn.

\section{Instructional / resource Materials used in TBLT.}

The findings showed that six (75\%) of the teachers out of eight used resource materials in all lessons, while 2 teachers used resource materials sometimes. This revealed the fact that there was no teacher who did not use. Another six teachers reported using audio-visual materials (audio tapes, DVDs, projectors, television, radio cassettes, CD's). This might have been because the use of audio-visual aids made teaching and learning easier as students were able to associate sounds and images. In addition, students will want to imitate the person talking which leads to faster acquisition of the language. According to Divya (2019) audio-visual method provides a variety of visual aids to both the teacher and learner which provides an opportunity to see, handle and manipulate.

As for the availability of resources, 5 out of 8 (63\%) of the teachers reported that the resources physical facilities such white interactive board, projectors, computers with internet connection and French room in teaching/learning French were available for teaching writing all the time. Two teachers $(25 \%)$ reported that the materials were available sometimes while one out of eight $(13 \%)$ teachers said that the resources were not available. Availability of these resources motivated both the teachers and students to be creative and innovative which helped in quality writing according to the sampled teachers. It was noted that some heads of schools were reluctant to purchase resource materials arguing that the number of students doing French was low compared to other subjects. Moreover, some principals preferred purchasing science equipment to French materials because sciences were compulsory in most of the schools. One out of eight of the teachers reported that he lacked knowledge on how to use the white board in teaching and how to download instructional materials from the internet. There was a possibility that although some schools might have purchased some resource materials, some schools might not have in serviced teachers on the use of these resources or have not purchased them at all because of financial constraints. Teachers are therefore encouraged to learn how to use the available resources or improvise their own resources in order to make TBLT more effective. Wanjiru (2009) in a study on instructional resources recommended that the administration should in-service teachers and ensure that they use teaching resources during their lessons.

Using the questionnaire, the sampled teachers were asked to tick on the type of resources relevant in TBLT in order to find out the extent to which this approach was being used. These included text books, authentic materials/ realia, audio visual materials and information communication and technology. Teachers went further to confirm that most of the topics in the KICD syllabus could be well taught using TBLT for example: buying and selling, asking and showing direction, writing of friendly and official letters and filling in the gaps exercises.

Table 3 shows the ranking of resources relevant for TBLT from number 1 to 6 .

\begin{tabular}{|cc|}
\hline Table 3 Resources in teaching quality writing \\
\hline Resource & Rank \\
\hline Textbooks & \\
\hline Entre Copains & 1 \\
\hline Au Sommet & 3 \\
\hline Parlons Français & 2 \\
Tour de Force & 6 \\
\hline Top Mark & 4 \\
\hline Access revision & 5 \\
\hline
\end{tabular}




\begin{tabular}{|cc|}
\hline Passeport Français & 6 \\
\hline $\begin{array}{c}\text { Grammaire progressive connections } \\
\text { Other resource materials }\end{array}$ & 6 \\
Magazines & 3 \\
Visual materials & 1 \\
Audio materials & 1 \\
Physical facilities & 3 \\
\hline
\end{tabular}

All the teachers (8), 100\% involved in the study revealed that they used all these resources and that they were relevant in TBA. According to table 4.5, all the teachers reported that the main textbook with many topics that could be taught using TBLT was Entre Copains. This resource was ranked number one among all the other resources. These results also correlated with the lesson observation guide which indicated that most of the teachers derived their content from Entre Copains. The lesson observation also revealed that most of the teachers were using this text book in class. This might have been because, a general reading through this text book, one would notice many writing tasks which enabled easier learning and teaching of quality writing.

From the study, 75\% of the teachers reported that they used Parlons Français which was ranked number 2 . This was a text book published by KICD, a factor that might have made it popular in teaching writing skills, having been authored by the support of the French Embassy in Kenya. The results showed that $63 \%$ of the teachers reported that Au Sommet was suitable for teaching writing as it contained many types of composition. Tour de France was the least relevant in teaching composition writing using TBLT. This might have been because according to the teachers, this text book did not contain many tasks that were important in taskbased teaching as reported by the teachers. Teachers and learners need to use textbooks that have a wide variety of tasks in order to make TBLT effective in French composition writing. The text books that teachers used are the ones recommended by the Kenya Institute of Curriculum Development (KICD) in the orange book for teaching French in secondary school in Kenya.

Teachers were asked to name some of the sites on the internet that can be used to teach writing.

Figure 1 shows the sites used in teaching French writing in percentages.

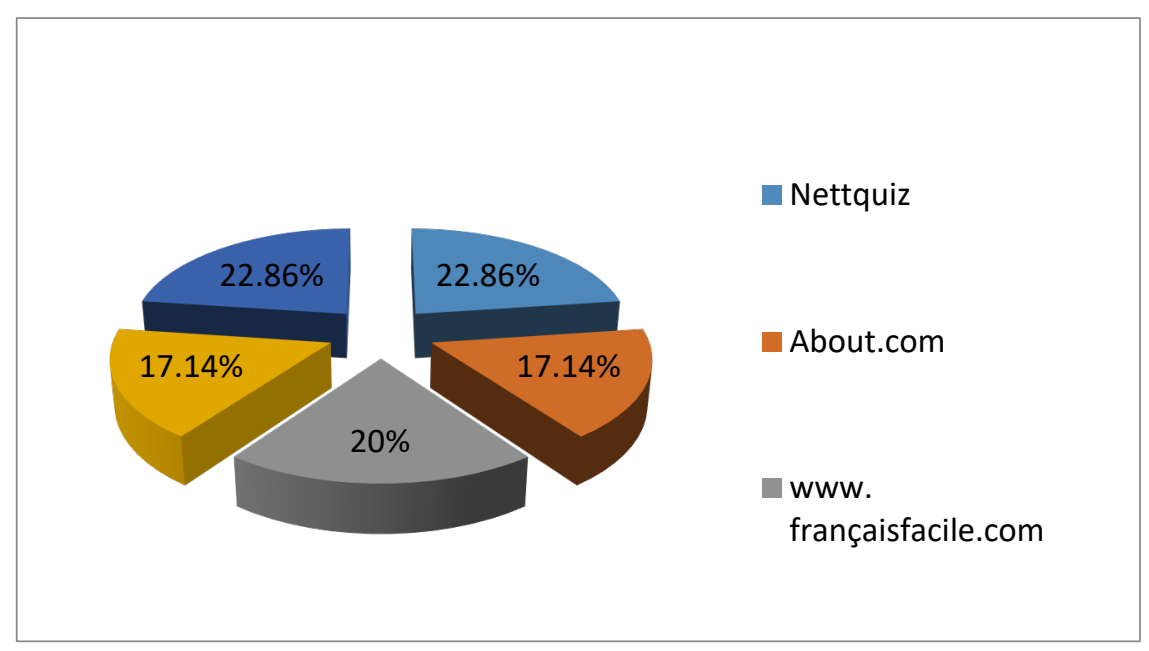

Figure 1 Sites used in quality writing

Figure 1 shows that the most used sites were Nettquiz and Podcast.bonjour de France with $22.86 \%$. The sites were commonly used may be because both the 
teacher and learner were able to access interesting writing tasks/activities. In fact, most of the students reported that the websites made it easier for them to do writing exercises and auto-correct as most of the activities had answers. This agrees with the finding by Mangenot (1987) who stated that learners do exercises on the internet and mark their work which enables them to see clearly where they went wrong and thus auto-correct their work. Therefore, this puts the learner at the center of the learning process, which is a major component in use of TBLT. Moreover, Gardner (1996) posits that Information

According to the sampled population about.com and la conjugaison.nouvel.com were rarely (17\%). This might be attributed to the fact that these sites have writing tasks that do not have answers and so learners found it had to auto-correct them. When an exercise on the internet does not have answers, it makes it difficult for the learner to continue attempting the questions. The teacher on the other hand may take a longer time coming up with answers. This activity may be time consuming bearing in mind that French in form 3 has been allocated only 2 hours per week by the Ministry of Education.

\section{Use of TBA in Assessment}

The researcher used the lesson observation guide to tick on what type of evaluation the teachers were using. These were; Teacher evaluating students, both teacher and students doing evaluation and student self-evaluation (autoevaluation) and students evaluating other students (Inter-evaluation). The evaluation methods were divided into two for ease of analysis, thus; Teachercentered (teacher marks students work) and Student Centered evaluation (student marks his/her own work) and a combination of the two. Figure 4.4 shows the method of evaluations that teachers used in quality writing.

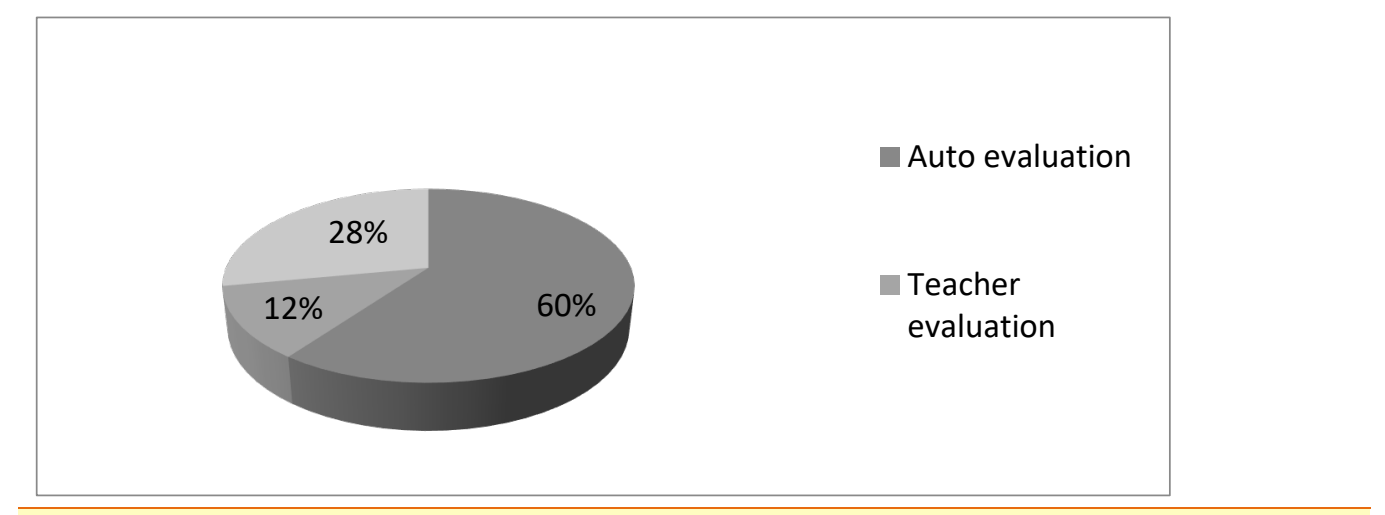

Figure 2 Types of evaluation used in class

According to the findings in Figure 2, a majority, (75\%) of teachers in the experimental group used auto evaluation after TBLT compared to $25 \%$ of teachers who had used it before TBLT. In the control group 63\% of the teachers used autoevaluation before and after the 6 weeks of teaching. This implied that in TBLT, the students were given an opportunity to correct their own work while the teacher guided them. All the teachers in the control group used both teacher and student evaluation compared to only 2 who had used it earlier while 3 teachers used it in the control group after the 6 weeks of teaching compared to the 1 teacher who had used it earlier. All the 4 teachers in the experimental group had used teacher evaluation before but after, only two were still using teacher evaluation while the rest employed other evaluation methods. TBLT recommends use of both methods of 
evaluation for it to be effective. Goullier (2006) argues that auto-evaluation helps students to identify their strong and weak areas.

Inter-evaluation was observed in one of the lessons although it was not one of the methods on the observation schedule. It was noted that this was equally an important assessment approach of TBLT as it encouraged peer- to- peer evaluation where students learnt from each other. These findings corroborate with the finding by Youssef (2010) stating that in TBLT, that teacher is no longer a dominator but a facilitator when it comes to evaluation of learners.

\section{REFERENCES}

Abdulbaki, K. (2018) The use of the Discussion method at University. Enhancement of Teaching and Learning. Muscat Oman. Retrieved from https://doi.org/10.5430/ijhe.v7n6p118

Adendorff, H. (2009) Task-Based Approach in acquisition of Afrikaans. Stellenbosch University. South Africa.

Altamirano (2018) Challenges of Implementing TBA in Argentina. Argentina.

Amadahe(2002) The importance of visual aids in teaching tasks in the English classroom. Cape Coast, Asante, K.O.

Ammon (1980) Task-Based Curriculum. Asia

Angriani, J. (2014) What is the role of program features?Journal of Policy,Practice and Research in Teacher Education. Vol 63 N.January/February 2012

Anjum, K. (2019) Fundamentals of Educational research methods. Cape Coast: university of Cape Coast Press.

Anol, B. (2012) Social Sciences Research: principles, methods and practices. University of South Florida

Arif \& Kimberly (2016) Research in teaching and learning a second language. South Africa

Arthur, B. E. (2014) Effects of Problem-Solving Approach on Mathematics achievement of Diploma in Basic Education Distance Learners at University of Cape Coast, Ghana. Unpublished Ph.D thesis. Kenyatta University.

Barile, P. (2014) Use of audio-visual method in teaching writing. CLE International. Paris

Belchamber, R. (2010). The Advantages of Communicative Language Teaching. The Internet TESL Journal Archives. Retrieved from www.iteslj.org/Articles/Belchamber-CLT.html

Besse H. (1985) Méthodes et Pratiques des Manuels de Langue, Paris, Didier/Crédif, Coll. Essais p. 165.

Boakye, C. (2017). Challenges and solutions: The Experiences of Newly Qualified Science Teachers. SAGE journals. Retrieved from https://doi.org/10.1177/2158244017706710

Brindley, S (2012): Discussion as a way of teaching. Tools and techniques for Democratic Classroom. 2nd edition. San Francisco: Jossey-Bass.

Bwire, A. M. (2007) Learner competencies and proficiency in English listening comprehension in selected secondary schools in Kenya. Ph. D Thesis

Cabral, S. W. (2009) Research Design. Qualitative, quantitative, and mixed methods approaches (3rd Ed.). Thousand Oaks, CA; SAGE Publications, Inc.

Carr \& Pauwels (2006) Content and Formal Schemata in ESL reading. TESOL Quarterly, 21,461-481. Retrieved from https://doi.org/10.2307/3586498 
Ceasar, A. (2018) Cognitive Task Analysis in Task-based Syllabus design for teaching of Kiswahili as a second language. Uganda.

Cashin, J. E. (2011) Listening Strategies of L2 learners with varied text tasks -TESL Canada Journal, 1-26

Clanfield, M. (2014) Practical use of TBA lesson plan in teaching grammar: TaskBased Approach. USA.

Clearinghouse, E. (1984). Training tutors for writing: Use of TBA in teaching writing skills. Urbana, Illinoise

Chokah,M,M. (2013) Training teachers of French in Kenya. International Journal of Education and Research. Volume 1 No. 9.

Connors, R. (1988) Frequency of Formal Errors in current college Writing - TESL Canada. Retrieved from https://doi.org/10.2307/357695

Creswel, J. W. (2009) Research Design. Qualitative, quantitative, and mixed methods approaches (3rd Ed.). Thousand Oaks, CA; SAGE Publications, Inc.

Crooks, R. (2012) Activities in TBLT. Canada

Dewey, J. (2009) Democracy and Education: An introduction to the philosophy of education. New York. WLC Books

Divya, M. (2019) Compte rendu de l'expérience: l'élaboration d'un curriculum dans le cadre d'un dispositive autonomisant. Mémoire de Master 2, Lille 3

Dornyei \& Clement (2001) Use of group-work in teaching. Canada

Ellis, R. (2003). Task-based Language Learning and Teaching. New York: Oxford.

Engestrom, Y (1999) Innovative Learning in work teams. Perspectives on Activity theory. Cambridge, Cambridge University Press.

Engestrom, Y. (1987) Learning by Expanding. Helsinki, Orienta-KonsultitOy.

Farahani, A. (2009) The effects of Task-Based Techniques, Gender and different levels of language proficieny on speaking development. University of Tehran

Farman (2018) Educational research: competencies for analysis and applications (9th ed). UpperSaddle River, New Jersey: Menrill Prentice Hall.

Gachathi (1976) Kenya Education Commission Report. National Government publication

Gardner (1996) Multiple intelligence. Paris, France 